\title{
GOLGA5 wt Allele
}

National Cancer Institute

\section{Source}

National Cancer Institute. GOLGA5 wt Allele. NCI Thesaurus. Code C97544.

Human GOLGA5 wild-type allele is located within $14 \mathrm{q}$ and is approximately $45 \mathrm{~kb}$ in length.

This allele, which encodes golg in subfamily A member 5 protein, plays a role in Golgi structure formation. Both mutation of the gene and a chromosomal translocation $t(10 ; 14)(q 11 ; q 32)$ of this gene and the RET gene are associated with thyroid papillary carcinoma. 